\title{
Inhibition of MMP-9 expression by ritonavir or saquinavir is associated with inactivation of the AKT/Fra-1 pathway in cervical intraepithelial neoplasia cells
}

\author{
ILARIA BACIGALUPO ${ }^{1}$, CLELIA PALLADINO ${ }^{1}$, PATRIZIA LEONE ${ }^{1}$, ELENA TOSCHI ${ }^{2}$, \\ CECILIA SGADARI ${ }^{1}$, BARBARA ENSOLI ${ }^{1}$ and GIOVANNI BARILLARI ${ }^{3}$ \\ ${ }^{1}$ National Acquired Immune Deficiency Syndrome Center; ${ }^{2}$ Department of Haematology, Oncology \\ and Molecular Medicine, National Institute of Health, I-00161 Rome; ${ }^{3}$ Department of Clinical Sciences \\ and Translational Medicine, University of Rome Tor Vergata, I-00133 Rome, Italy
}

Received December 15, 2015; Accepted October 19, 2016

DOI: $10.3892 / 01.2017 .5835$

\begin{abstract}
A reduced incidence and decreased clinical progression of uterine cervical intraepithelial neoplasia (CIN) has been observed in women infected with human immunodeficiency virus (HIV) treated with HIV-protease inhibitors (PIs). The HIV-PIs saquinavir (SQV) and ritonavir (RTV) have been demonstrated to efficiently inhibit invasion of human primary CIN cells by downregulating the expression of matrix metalloproteinase (MMP)-9. The present study further investigated the molecular mechanisms underlying the activity of SQV and RTV in CIN. The results of the present study indicate that the treatment of human primary CIN cells with SQV or RTV directly impairs events leading to MMP-9 expression, including the phosphorylation of AKT and the nuclear localisation of the Fos-related antigen transcription factor. In addition, neither SQV nor RTV affected the expression of human papilloma virus proteins, such as E6 or E7. In view of the important role that the AKT/Fra-1/MMP-9 signalling pathway serves in CIN progression to invasive cervical carcinoma, these data further support the use of HIV-PIs in the treatment of CIN in women infected with HIV and women who are not infected with HIV. Furthermore, the present study identified a molecular mechanism underlying the anti-invasive effects of SQV/RTV, providing useful information for the development of SQV/RTV derivatives, which may be employed as novel anticancer drugs.
\end{abstract}

Correspondence to: Professor Giovanni Barillari, Department of Clinical Sciences and Translational Medicine, University of Rome Tor Vergata, 1 Montpellier Street, I-00133 Rome, Italy E-mail: barillar@uniroma2.it

Key words: human immunodeficiency virus-protease inhibitors, uterine cervical intraepithelial neoplasia, matrix metalloproteinase-9, AKT, Fos-related antigen-1, high-risk human papilloma viruses

\section{Introduction}

Infection of the uterine cervix by an oncogenic, high-risk (HR)-human papilloma virus (HPV) frequently results in low-grade cervical intraepithelial neoplasia (CIN), a dysplastic lesion that may progress into high-grade CIN and cervical carcinoma (1). The prevalence and persistence of HR-HPV, the incidence of CIN and the risk of CIN progression are high in women infected with HR-HPV and human immunodeficiency virus (HIV) (1). In these patients, antiretroviral drugs, including HIV-protease inhibitors (PIs), have reduced the rate of uterine CIN incidence and progression (2-4).

The progression of CIN to invasive cervical carcinoma is initiated when HR-HPV ${ }^{+}$keratinocytes invade the basement membrane at the stromal/epithelial junction of the lesion (1). A previous study demonstrated that therapeutic concentrations of HIV-PIs, such as saquinavir (SQV) and ritonavir (RTV), effectively inhibit the invasive capabilities of $\mathrm{HR}-\mathrm{HPV}^{+}$human primary keratinocytes obtained from low-grade CIN lesions (5). This inhibition of invasion was associated with the downregulation of the pro-invasive, basement membrane-degrading enzyme matrix metalloproteinase (MMP)-9 and, to a lesser extent, with the downregulation of MMP-2 (5). As these results were obtained in an in vitro experimental model devoid of HIV or immune cells, they confirm preclinical and clinical work indicating that HIV-PIs exert direct antitumour effects independently of their anti-HIV and/or immune reconstituting activities (5-14).

The capability of SQV and RTV to inhibit the expression of MMP-9 has important implications, since MMP-9 serves a key role in the invasion and clinical progression of CIN (15-18). A previous study identified that MMP-9 expression is induced in CIN cells by epidermal growth factor (EGF) (5), which is a marker of CIN progression (19). Another study demonstrated that the induction of MMP-9 expression by EGF in epithelial cells is preceded and/or accompanied by the phosphorylation and activation of signalling molecules, including the serine/threonine kinase AKT (20). EGF-induced phosphorylation of AKT leads to the activation of members of the activator protein-1 transcriptional complex, such as 
Fos-related antigen (Fra)-1 (21), which is a potent activator of MMP-9 gene expression (22-24). Notably, the E6 and E7 proteins of HR-HPV have been shown to phosphorylate AKT $(25,26)$ and to promote MMP-9 expression $(27,28)$. In view of the inhibitory effect of SQV/RTV on CIN cell invasion and MMP-9 expression, the present study investigated whether therapeutic concentrations of these HIV-PIs would affect the AKT/Fra-1 signalling pathway or the expression of E6/E7 in $\mathrm{HR}-\mathrm{HPV}^{+}$human primary CIN cells.

\section{Materials and methods}

Reagents. SQV (Roche Diagnostics, Basel, Switzerland) and RTV (National Institutes of Health, Bethesda, MD, USA) were diluted and handled as previously described (5). Cell growth medium (DMEM/Ham's F12 enriched with $\mathrm{NaHCO}_{3}$, HEPES, $\mathrm{HCl}$, penicillin and streptomycin), PBS and monoclonal antibodies raised against the E7 protein of HPV16 (dilution, 1:200; catalog no. MA5-15822) were purchased from Thermo Fisher Scientific, Inc. (Waltham, MA, USA). Sigma-Aldrich (Merck Millipore, Darmstadt, Germany) was the source of growth media supplements (fetal bovine serum, hydrocortisone, adenine, insulin, transferrin, cholera enterotoxin and 3,3',5-triiodo-L-thyronine), anti $\beta$-actin monoclonal antibodies (dilution, 1:1,000; catalog no. A5316), bovine serum albumin (BSA; fraction V) and the chemicals employed for protein extraction, which included Tris $\mathrm{HCl}, \mathrm{NaCl}, \mathrm{MgCl}_{2}$, $\mathrm{KCl}$, Nonidet P (NP)-40, sodium deoxycholate, phenylmethyl-sulfonyl fluoride (PMSF), dithiothreitol (DTT), EDTA, glycerol, HEPES, leupeptin, aprotinin, or pepstatin. Monoclonal antibodies directed against the E6 protein of HPV16 (dilution, 1:200; catalog no. sc-460) or human C23 (nucleolin; dilution, 1:250; catalog no. sc-515312) were obtained from Santa Cruz Biotechnology, Inc. (Dallas, TX, USA). Rabbit monoclonal antibodies raised against Fra-1 (dilution, 1:250; catalog no. 5281) or phosphorylated AKT (ser473; dilution, 1:250; catalog no. 4060) were obtained from Cell Signaling Technology, Inc. (Danvers, MA, USA). The primers and probes employed for RNA analyses were purchased from Applied Biosystems (Thermo Fisher Scientific, Inc.). Human recombinant EGF was purchased from BD Biosciences (Franklin Lakes, NJ, USA), and suspended in $0.1 \%$ BSA in PBS.

Cell culture. W12 (HPV16 $)$ and CIN612-7E (HPV31+) human primary keratinocyte cell lines, derived from low-grade CIN in HIV-negative women were obtained, characterised and cultured as previously described $(29,30)$. In all experiments, cells were cultured for $96 \mathrm{~h}$ in the absence or presence of $10 \mu \mathrm{M}$ SQV or RTV, which were added to the growth medium on a daily basis (5). Subsequently, cells were exposed to EGF or its suspension buffer $(0.1 \%$ BSA in PBS) for $15,30,60$ or $90 \mathrm{~min}$, or $3,6,12$ or $96 \mathrm{~h}$, in the presence or absence of SQV or RTV.

Invasion assays and zymography. The effect of SQV and RTV on W12 cell invasion was assayed using the Boyden chambers (5), as previously described. At the end of the assay, invaded cells were fixed in ethanol (Sigma-Aldrich), stained with toluidine blue (Sigma-Aldrich), and quantitated using light microscopy, counting 5 fields/filter (5). With regard to zymography, W12 cells were cultured overnight in EGF-supplemented, serum-free medium, in the absence or presence of SQV or RTV. Cell supernatants were collected and concentrated with the use of Centricon centrifugal filter devices (Merck Millipore). Protein concentration was determined with Bradford reagent (Bio-Rad, Hercules, CA, USA), using BSA as a standard. To detect collagenolytic activity, $2 \mu \mathrm{g}$ total proteins from concentrated supernatants were electrophoresed using 9\% SDS PAGE embedded with $1 \mathrm{mg} / \mathrm{ml}$ gelatin (Sigma-Aldrich), as described (31). Following staining with Coomassie blue (Bio-Rad), the decrease in staining of each band due to protease activity was quantified using densitometry (5).

Reverse transcription-quantitative polymerase chain reaction $(R T-q P C R)$. Total RNA was extracted from the cells, purified, and used to synthesize complementary DNA (cDNA), as previously described (5). The reverse-transcribed (RT) cDNA from repeated, independent experiments was used for quantitative (q)PCR analysis of MMP-9 (Hs_MMP9_1_SG Quantitect Primer Assay; Qiagen, Inc., Valencia, CA, USA). The reaction was normalized by amplifying samples for glyceraldehyde-3-phosphate dehydrogenase as the reference gene (Hs_GAPDH_2_SG Quantitect Primer Assay; Qiagen). RT-PCR was performed, and the data were analyzed, as reported previously (5).

In other experiments, cDNA was used for PCR analysis of HPV-E6 or HPV-E7, according the TaqMan technique. Specifically, 2X TaqMan gene expression master mix (Thermo Fisher Scientific) was employed, while primers or probes were used at 0.9 or $0.2 \mu \mathrm{M}$, respectively. The following primers were used for qPCR: HPV16-E6 forward (F), 5'-AATGTTTC AGGACCCACAGG-3' and reverse (R), 5'-TTGTTTGCAGCT CTGTGCAT-3'; HPV16-E7 F, 5'-CAAGTGTGACTCTACGC TTCGG-3' and R, 5'-GTGGCCCATTAACAGGTCTTC CAA-3'; HPV31-E6 F, 5'-ATTCCACAACATAGGAGGAA GGT-3' and R, 5'-CACTTGGGTTTCAGTACGAGGTCT-3'; HPV31-E7 F, 5'-GGCAACTGACCTCCACTGTT-3' and R, 5'-ATTGGATGTGTCCGGTTCTG-3'; and $\beta$ actin F, 5'-AAG AGCTACGAGCTGCCTGA 3' and R, 5'-TGGAGTTGAAGG TAGTTTCGTG-3'. The probes used were as follows: HPV16-E6, 5'-AGC GAC CCA GAA AGT TAC CA-3'; HPV16-E7, 5'-TGCGTACAAAGCACACACGTAGACATT CGT-3'; HPV31-E6, 5'-ACAGGACGTTGCATAGCATGT TGGA-3'; HPV31-E7, 5'-ATGAGCAATTACCCGACAGC-3'; and $\beta$ actin, 5'-CATCACCATTGGCAATGAGCGGT-3'.

In order to visualize the probes, these were conjugated to tetramethyl-rhodamine (Thermo Fisher Scientific, Inc.). qPCR thermocycling conditions were as follows: 45 cycles of $20 \mathrm{sec}$ at $50^{\circ} \mathrm{C}, 10 \mathrm{~min}$ at $95^{\circ} \mathrm{C}$ and $15 \mathrm{sec}$ at $95^{\circ} \mathrm{C}$, followed by $1 \mathrm{~min}$ at $58^{\circ} \mathrm{C}$. PCR data were analyzed using the 7500 Fast System SDS software (version 2.0.5; Applied Biosystems, Thermo Fisher Scientific, Inc.), and the results were normalized to $\beta$-actin. The complexes formed by PCR products and associated probes were quantified by employing the $2^{-\Delta \Delta C q}$ method (32).

Western blot analysis., To extract total proteins, W12

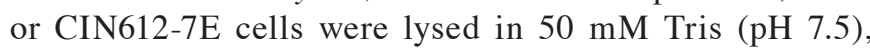
$150 \mathrm{mM} \mathrm{NaCl}, 1 \%$ NP-40, 0.25/sodium deoxycholate, $1 \mathrm{mM}$ 
A

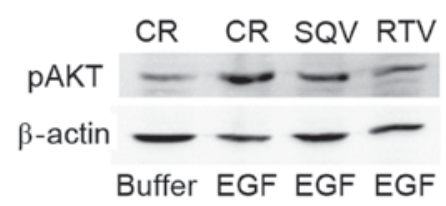

Buffer EGF EGF EGF

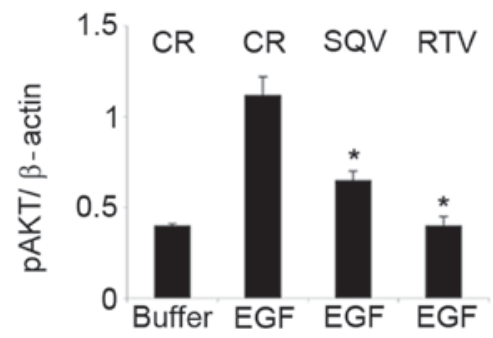

0.75

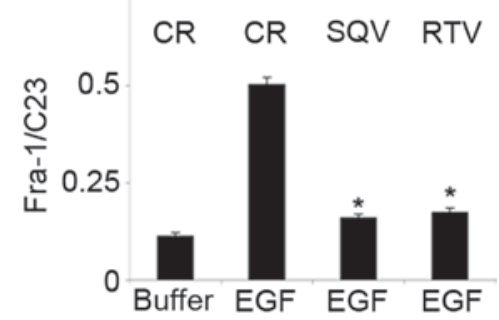

Figure 1. SQV and RTV inhibit AKT phosphorylation and reduce nuclear Fra-1 protein levels in EGF-stimulated CIN612-7E cells. CIN612-7E cells were cultured for $96 \mathrm{~h}$ in the presence of $10 \mu \mathrm{M} \mathrm{SQV}$ or RTV. CIN612-7E cells cultured without SQV/RTV were employed as the control. Cells were subsequently exposed to $50 \mathrm{ng} / \mathrm{ml}$ human recombinant EGF, or to its suspension buffer ( $0.1 \%$ bovine serum albumin in phosphate-buffered saline). (A) Cells were lysed following a 30-min exposure to EGF, and their total protein content was analysed by western blotting, followed by quantification of pAKT protein expression (relative to $\beta$-actin) by densitometry. (B) Cells were lysed following a 6-h exposure to EGF, and their nuclear protein content was analysed via western blotting, followed by quantification of nuclear Fra-1 protein levels (relative to C23) by densitometry. Results are presented as the mean \pm standard deviation from three experiments. ${ }^{*}<0.05$ vs. the control group. SQV, saquinavir; RTV, ritonavir; Fra-1, Fos-related antigen 1; CR, control; EGF, epidermal growth factor; p, phosphorylated.

PMSF, $2 \mathrm{mM}$ ethyleneglycol-bis ( $\beta$-aminoethyl ether)-N,N, $\mathrm{N}$-tetraacetic acid, $30 \mu \mathrm{g} / \mathrm{ml}$ leupeptin and $10 \mu \mathrm{g} / \mathrm{ml}$ aprotinin. To evaluate phosphorylated AKT levels, W12 or CIN612-7E cells were lysed in $40 \mathrm{mM}$ Tris (pH 8.0), $120 \mathrm{mM} \mathrm{NaCl}$ and $0.1 \% \mathrm{NP}-40$, and kept in ice for $30 \mathrm{~min}$. Cellular lysate was centrifuged at $13,000 \times \mathrm{g}$ for $15 \mathrm{~min}$ at $4^{\circ} \mathrm{C}$, and the cleared supernatant was then collected. To obtain nuclear protein, W12 or CIN612-7E cells were lysed in $10 \mathrm{mM}$ HEPES pH 7.9, $1.5 \mathrm{mM} \mathrm{MgCl}_{2}, 10 \mathrm{mM} \mathrm{KCl}, 0.5 \mathrm{mM}$ PMSF, 0.5 DTT, 0.1\% NP-40, $10 \mu \mathrm{g} / \mathrm{ml}$ leupeptin, $10 \mu \mathrm{g} / \mathrm{ml}$ pepstatin and $5 \mu \mathrm{g} / \mathrm{ml}$ aprotinin. Nuclei were separated by centrifugation $(13,000 \mathrm{x} g$ for $15 \mathrm{~min}$ at $4^{\circ} \mathrm{C}$ ), suspended in $20 \mathrm{mM}$ HEPES (pH 7.9), $0.42 \mathrm{M} \mathrm{NaCl}, 1.5 \mathrm{mM} \mathrm{MgCl}{ }_{2}, 0.2 \mathrm{mM}$ EDTA, 25\% glycerol, $0.5 \mathrm{mM}$ PMSF, $0.5 \mathrm{mM}$ DTT, $10 \mu \mathrm{g} / \mathrm{ml}$ leupeptin, $10 \mu \mathrm{g} / \mathrm{ml}$ pepstatin and $5 \mu \mathrm{g} / \mathrm{ml}$ aprotinin, and kept in ice for $60 \mathrm{~min}$. Nuclear lysate was sonicated, centrifuged at $13,000 \times \mathrm{g}$ for $15 \mathrm{~min}$ at $4^{\circ} \mathrm{C}$ and the cleared supernatant was then collected.

Protein content in cell lysates was assayed with Bradford reagent (Bio-Rad). Proteins from each sample were separated onto 10 or $12 \%$ SDS-PAGE and transferred onto Hybond nitrocellulose membrane filters (GE Healthcare Life Sciences, Pittsburgh, PA, USA), which were probed with primary antibodies and the corresponding secondary horseradish peroxidase-conjugated antibodies, as previously described (33). Bands were visualised using LiteAblot ${ }^{\circledR}$ PLUS Enhanced Chemiluminescent Substrate (Euroclone SpA, Milan, Italy), and the intensity of the bands was quantified relative to $\beta$-actin using the ChemiDoc XRS+ system (Bio-Rad Laboratories S.r.l., Segrate, Italy).

Statistical analysis. Data are expressed as the mean \pm standard deviation from three independent experiments. Statistical analysis was performed using the SPSS 15.0 software (SPSS
Inc., Chicago, IL, USA). P-values were determined with Student's $t$-test. $\mathrm{P}<0.05$ was considered to indicate a statistically significant difference.

\section{Results}

Prior research indicated that EGF triggers the invasion of HR-HPV $31^{+}$CIN cells through inducing MMP-9 expression, and that this effect is strongly inhibited by exposure of CIN cells to $10 \mu \mathrm{M}$ SQV or RTV for 72-96 h (5). This concentration of SQV/RTV corresponds to the drugs' peak plasma levels in treated individuals (5). In the present study, initial experiments investigated the molecular mechanisms underlying the inhibitory effect exerted by SQV/RTV on MMP-9 expression. These experiments were conducted in HR-HPV $31^{+}$human primary CIN612-7E cells.

Consistent with previous data obtained in cells of epithelial origin (20), the present study identified that EGF promoted AKT phosphorylation in CIN cells (Fig. 1A). This effect was demonstrated to be dose and time dependent, with AKT phosphorylation peaking at $30 \mathrm{~min}$ in the presence of $50 \mathrm{ng} /$ $\mathrm{ml}$ EGF (data not shown). Since SQV and RTV impair AKT phosphorylation $(12,13)$, the impact of these HIV-PIs on EGF-induced AKT phosphorylation was assessed. A concentration of $10 \mu \mathrm{M} \mathrm{SQV/RTV}$, a therapeutic concentration that inhibits EGF-induced CIN cell invasion and MMP-9 expression (5), significantly reduced the phosphorylation of AKT in CIN612-7E cells compared with the control group (SQV, $\mathrm{P}=0.047$; RTV, $\mathrm{P}=0.024$; Fig. 1A).

In agreement with a previous study in epithelial cells (21), $50 \mathrm{ng} / \mathrm{ml}$ EGF was observed to augment Fra-1 protein levels in CIN cell nuclei (Fig. 1B). This effect was time dependent, peaking at $6 \mathrm{~h}$ and declining thereafter (data not shown). 
A

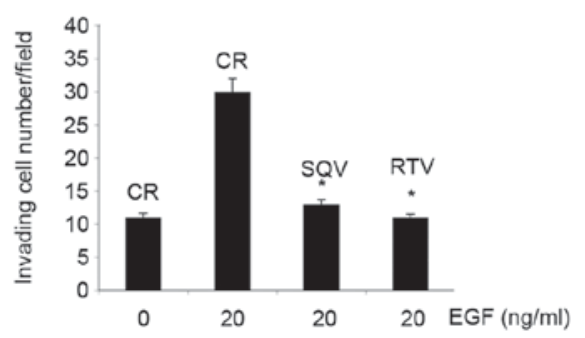

D

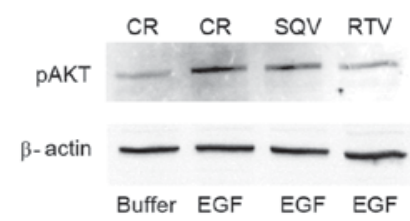

B

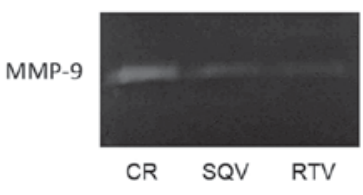

C

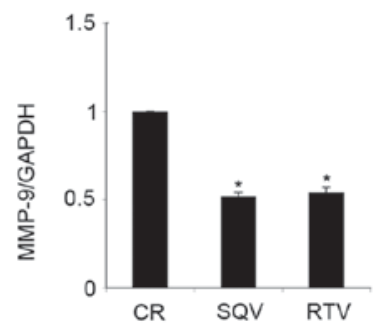

$\mathbf{E}$
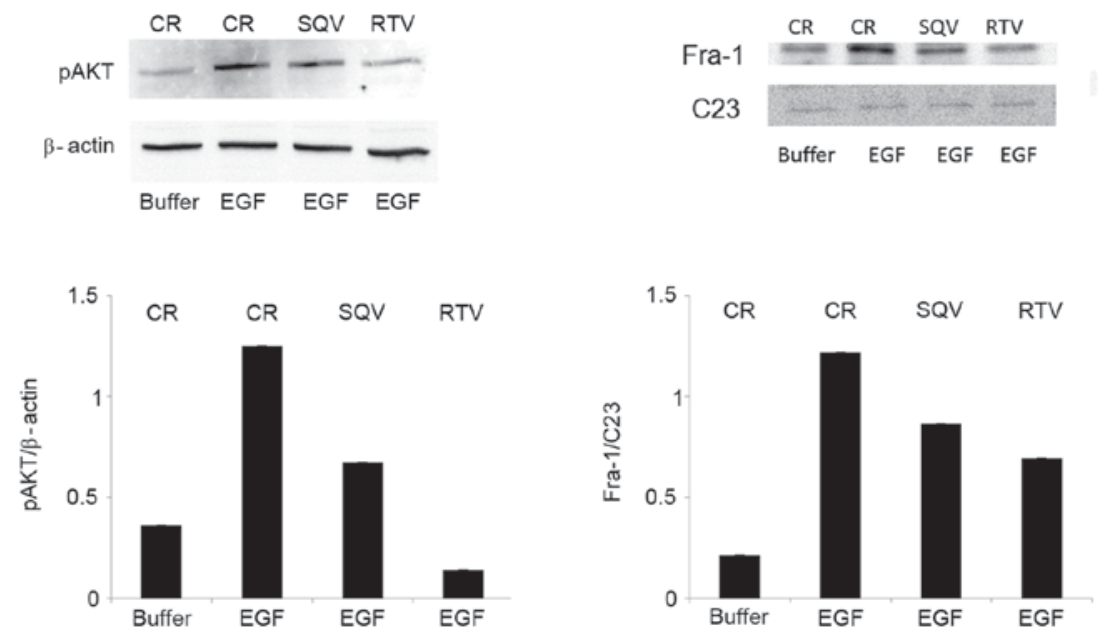

Figure 2. SQV and RTV counteract EGF-induced cell invasion, MMP-9 expression, AKT phosphorylation and nuclear Fra-1 protein expression in W12 cells. W12 cells were cultured for $96 \mathrm{~h}$ in the presence of $10 \mu \mathrm{M} \mathrm{SQV}$ or RTV, or in their absence (control). (A) Cells were stimulated to invade a reconstituted basement membrane in response to $20 \mathrm{ng} / \mathrm{ml}$ human recombinant EGF, or to its suspension buffer $(0.1 \%$ bovine serum albumin in phosphate-buffered saline, indicated here as EGF $0 \mathrm{ng} / \mathrm{ml}$ ). Results are expressed as the mean \pm standard deviation from 3 experiments, each performed in duplicate chambers. (B) Representative zymography of EGF-supplemented, serum-free supernatants. The de-stained areas indicate gelatinolytic activity corresponding to MMP-9 (92 kDa) released by the cells. (C) Reverse transcription-quantitative polymerase chain reaction analysis of MMP-9 messenger RNA levels (relative to GADPH) in cells cultured in EGF-supplemented growth medium, in the absence or presence of $10 \mu \mathrm{M} \mathrm{SQV} / \mathrm{RTV}$. Results are expressed as the mean \pm standard deviation from 3 experiments. (D) Representative western blot analysis and quantification by densitometry of pAKT protein levels (relative to $\beta$-actin) in W12 cells lysed following a 30-min exposure to EGF. (E) Representative western blot analysis and quantification by densitometry of nuclear Fra-1 protein levels (relative to C23) in W12 cells lysed following a 6-h exposure to EGF. "P<0.05 vs. the control group. SQV, saquinavir; RTV, ritonavir; Fra-1, Fos-related antigen 1; CR, control; p, phosphorylated; MMP, matrix metalloproteinase; EGF, epidermal growth factor.

SQV/RTV significantly reduced Fra-1 content in the nuclei of EGF-stimulated CIN612-7E cells compared with the control group (SQV, P=0.048; RTV, P=0.035; Fig. 1B). The E6 or E7 proteins of HR-HPV are known to phosphorylate AKT and promote MMP-9 expression (25-28). Thus, experiments were performed in order to evaluate whether the inhibitory effect that SQV/RTV exert on AKT phosphorylation and MMP-9 expression paralleled a reduction in E6/E7 protein levels in CIN612-7E cells. However, this was not assessed, as antibodies directed against the E6 or E7 proteins of HPV31 were not commercially available, and antibodies raised against the E6 or E7 proteins of HPV16 did not recognise the HPV31 E6 or E7 proteins expressed by CIN612-7E cells.

Further experiments employing W12 cells, HPV16 ${ }^{+}$ human primary keratinocytes derived from low-grade CIN lesions (29), were performed. Confirmatory experiments indicated that, as for HPV $31^{+}$CIN cells (5), a 96-h exposure to $10 \mu \mathrm{M} \mathrm{SQV}$ or RTV significantly inhibited cell invasion compared with the control group ( $\mathrm{SQV}, \mathrm{P}=0.008$; RTV, $\mathrm{P}=0.006$; Fig. 2A), markedly reduced MMP-9 proteolytic activity (Fig. 2B) and significantly downregulated MMP-9 expression ( $\mathrm{SQV}, \mathrm{P}=0.008$; RTV, $\mathrm{P}=0.010$; Fig. 2C). Notably,
SQV and RTV produced these effects in low-passage, but not in high-passage, W12 cells (data not shown). Additional experiments demonstrated that, compared with control cells, SQV and RTV notably reduced EGF-induced AKT phosphorylation in W12 cells (Fig. 2D). Furthermore, SQV/RTV reduced Fra-1 content in the nuclei of EGF-stimulated W12 cells (Fig. 2E), similarly to the results obtained with HPV $31^{+}$ CIN612-7E cells.

Assays using antibodies raised against the E6 and E7 proteins of HPV16 demonstrated that SQV/RTV did not modify the content of these proteins in W12 cells (Fig. 3A and $\mathrm{B}$ ). In addition, neither of the HIV-PIs tested altered the messenger RNA (mRNA) levels of HPV16 E6 or E7 in W12 cells (Fig. 3C). Similarly, SQV/RTV did not affect the mRNA expression of HPV31 E6 (Fig. 3C) or E7 (Fig. 3D) in CIN612-7E cells.

\section{Discussion}

It has previously been demonstrated that $\mathrm{SQV} / \mathrm{RTV}$, at concentrations present in the plasma of treated patients, efficiently inhibit EGF-induced invasion of HR-HPV $31^{+}$CIN cells via 
A
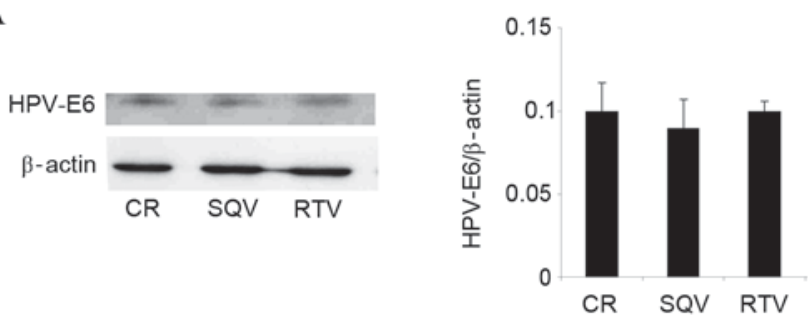

B

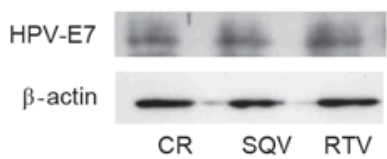

$\mathrm{C}$

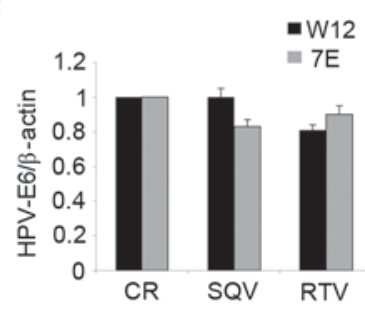

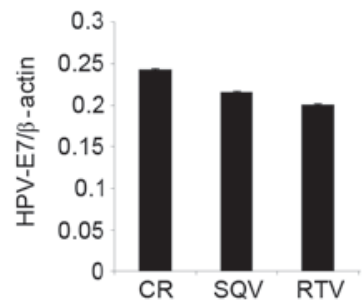

$\mathrm{D}$

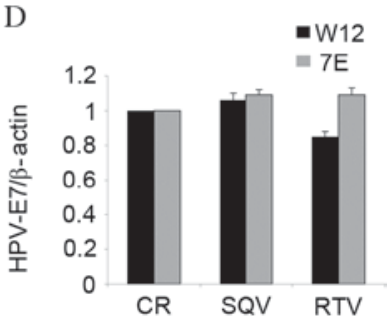

Figure 3. SQV and RTV have no significant effect on HPV E6 and E7 expression in CIN cells. W12 and CIN612-7E cells were cultured for $96 \mathrm{~h}$ in EGF-supplemented growth medium, in the presence of $10 \mu \mathrm{M} \mathrm{SQV}$ or RTV. Cells cultured without SQV/RTV were employed as controls. W12 cells were lysed, and their total protein content was analysed by western blotting, followed by quantification (relative to $\beta$-actin) via densitometry using antibodies directed against the (A) E6 or (B) E7 proteins of HPV16. Reverse transcription-quantitative polymerase chain reaction analysis of (C) E6 and (D) E7 messenger RNA levels (relative to $\beta$-actin) in W12 and CIN612-7E cells. Results are presented as the mean \pm standard deviation from three experiments. SQV, saquinavir; RTV, ritonavir; CR, control; HPV, human papilloma virus.

reducing MMP-9 expression (5). This explains the results of clinical studies that observed HIV-PI efficacy against uterine CIN (2-4). The present study confirmed the anti-invasive activities of SQV/RTV in HPV $16^{+}$CIN cells. In addition, to the best of our knowledge, the present study demonstrated for the first time that, in HPV $16^{+}$and HPV $31^{+}$CIN cells, inhibition of EGF-induced MMP-9 expression by SQV/RTV is preceded by a reduction in AKT phosphorylation. This is consistent with previous results obtained in other models, which indicated that HIV-PIs can counteract AKT phosphorylation $(12,13)$, and that compounds abrogating EGF-induced AKT phosphorylation inhibit MMP-9 expression and cell invasion (20).

Indeed, the capability of SQV/RTV to impair AKT phosphorylation in CIN cells may have clinical relevance. Levels of phosphorylated AKT in epithelial cells change during the different stages of cervical carcinogenesis. Specifically, phosphorylated AKT is absent in the normal uterine cervix, while it is present in CIN biopsies and further increased in cervical carcinoma $(34,35)$. In agreement with previous studies that observed that Fra-1 silencing reduces MMP-9 expression and cell invasion (22), the present study demonstrated that inhibition of MMP-9 expression by RTV/SQV is associated with a

reduction in nuclear, transcriptionally active Fra-1 protein in CIN cells.

The current study identified that the inhibitory effect of RTV/SQV on MMP-9 expression is not accompanied with the downregulation of E6 or E7, two HPV oncogenes that trigger AKT phosphorylation and MMP-9 expression in infected cells (25-28). Nevertheless, the present and previous results (5) suggest that the effectiveness of RTV/SQV against uterine CIN is influenced by HPV, in particular by its integration into the host cell genome. Specifically, the present study demonstrated that SQV and RTV downregulate MMP-9 expression in low-passage, but not in high-passage, W12 cells. In this regard, it must be highlighted that W12 cells retain HPV16 in an episomic (not integrated) form during early passages, while long-term in vitro cultivation of the cells leads to spontaneous loss of episomes and selection of cells containing only integrated HPV16 (29).

It has previously been identified that $\mathrm{SQV}$ and RTV reduce MMP-9 expression in CIN612 cells independently of their passage status, while having little or no effect on cell lines derived from late-stage carcinoma of the uterine cervix (5). CIN612 cells permanently maintain HPV31 DNA in an episomic form (30), while cervical carcinoma cells possess integrated HPV genomes (36). Since HPV episomes are present in low-grade CIN, while integrated HPV is characteristic of invasive cervical carcinomas (37), these results indicate that SQV and RTV could be effective therapeutic agents for the treatment of CIN, but may be less effective against cervical carcinoma. Although this hypothesis is supported by previous clinical observations $(4,38)$, further study is required to verify it.

In conclusion, in view of the high incidence of CIN in HIV-infected women (1), the results of the present study support the continued employment of HIV-PIs in HIV treatment regimens. In addition, considering the key role that MMP-9 serves in CIN progression to invasive cervical carcinoma (15-18), the results of the current study support the use of SQV, RTV or their derivatives for the treatment of CIN in HIV-negative women. These recommendations are supported by the low toxicity of SQV/RTV and the large quantity of data available regarding their pharmacokinetics (39).

\section{Acknowledgements}

The present study was supported by the Italian Ministry of Health (Rome, Italy; grant no. OR/70DF) and the Italian Ministry of Education, University and Research (Rome, Italy; grant no. RSA/0906). The authors would like to thank Professor L.A. Laimins (Northwestern University, Chicago, IL, USA) for providing the W12 and CIN612-7E cells, and Dr M. Falchi (National AIDS Center, Rome, Italy) for assistance in preparing the figures.

\section{References}

1. Denslow SA, Rositch AF, Firnhaber C, Ting J and Smith JS: Incidence and progression of cervical lesions in women with HIV: A systematic global review. Int J STD AIDS 25: 163-177, 2014.

2. Heard I, Schmitz V, Costagliola D, Orth G and Kazatchkine MD: Early regression of cervical lesions in HIV-seropositive women receiving highly active antiretroviral therapy. AIDS 12: 1459-1464, 1998. 
3. Omar T, Schwartz S, Hanrahan C, Modisenyane T, Tshabangu N, Golub JE, McIntyre JA, Gray GE, Mohapi L and Martinson NA: Progression and regression of premalignant cervical lesions in HIV-infected women from Soweto: A prospective cohort. AIDS 25: 87-94, 2011.

4. Blitz S, Baxter J, Raboud J, Walmsley S, Rachlis A, Smaill F, Ferenczy A, Coutlée F, Hankins C and Money D; Canadian Women's HIV Study Group: Evaluation of HIV and highly active antiretroviral therapy on the natural history of human papillomavirus infection and cervical cytopathologic findings in HIV-positive and high-risk HIV-negative women. J Infect Dis 208: 454-462, 2013

5. Barillari G, Iovane A, Bacigalupo I, Palladino C, Bellino S, Leone P, Monini P and Ensoli B: Ritonavir or saquinavir impairs the invasion of cervical intraepithelial neoplasia cells via a reduction of MMP expression and activity. AIDS 26: 909-919, 2012.

6. Sgadari C, Barillari G, Toschi E, Carlei D, Bacigalupo I, Baccarini S, Palladino C, Leone P, Bugarini R, Malavasi L, et al: HIV protease inhibitors are potent anti-angiogenic molecules and promote regression of Kaposi sarcoma. Nat Med 8: 225-232, 2002.

7. Monini P, Sgadari C, Toschi E, Barillari G and Ensoli B: Antitumour effects of antiretroviral therapy. Nat Rev Cancer 4: $861-875,2004$

8. Brunner TB, Geiger M, Grabenbauer GG, Lang-Welzenbach M Mantoni TS, Cavallaro A, Sauer R, Hohenberger W and McKenna WG: Phase I trial of the human immunodeficiency virus protease inhibitor nelfinavir and chemoradiation for locally advanced pancreatic cancer. J Clin Oncol 26: 2699-2706, 2008.

9. Monini P, Sgadari C, Grosso MG, Bellino S, Di Biagio A, Toschi E, Bacigalupo I, Sabbatucci M, Cencioni G, Salvi E, et al Clinical course of classic Kaposi's sarcoma in HIV-negative patients treated with the HIV protease inhibitor indinavir. AIDS 23: 534-538, 2009.

10. Rengan R, Mick R, Pryma D, Rosen MA, Lin LL, Maity AM, Evans TL, Stevenson JP, Langer CJ, Kucharczuk J, et al: A phase I trial of the HIV protease inhibitor nelfinavir with concurrent chemoradiotherapy for unresectable stage IIIA/IIIB non-small cell lung cancer: A report of toxicities and clinical response. J Thorac Oncol 7: 709-715, 2012.

11. Barillari G, Iovane A, Bacigalupo I, Labbaye C, Chiozzini C, Sernicola L, Quaranta MT, Falchi M, Sgadari C and Ensoli B: The HIV protease inhibitor indinavir down-regulates the expression of the pro-angiogenic MT1-MMP by human endothelial cells. Angiogenesis 7: 831-838, 2014.

12. Batchu RB, Gruzdyn OV, Bryant CS, Qazi AM, Kumar S, Chamala S, Kung ST, Sanka RS, Puttagunta US, Weaver DW and Gruber SA: Ritonavir-mediated induction of apoptosis in pancreatic cancer occurs via the RB/E2F-1 and AKT pathways. Pharmaceuticals (Basel) 7: 46-57, 2014.

13. Kraus M, Müller-Ide H, Rückrich T, Bader J, Overkleeft $\mathrm{H}$ and Driessen C: Ritonavir, nelfinavir, saquinavir and lopinavir induce proteotoxic stress in acute myeloid leukemia cells and sensitize them for proteasome inhibitor treatment at low micromolar drug concentrations. Leuk Res 38: 383-392, 2014.

14. Sato A: The human immunodeficiency virus protease inhibitor ritonavir is potentially active against urological malignancies Onco Targets Ther 8: 761-768, 2015.

15. Libra M, Scalisi A, Vella N, Clementi S, Sorio R, Stivala F, Spandidos DA and Mazzarino C: Uterine cervical carcinoma: Role of matrix metalloproteinases (Review). Int J Oncol 34: 897-903, 2009.

16. Talvensaari-Mattila A and Turpeenniemi-Hujanen T: Matrix metalloproteinase 9 in the uterine cervix during tumor progression. Int J Gynaecol Obstet 92: 83-84, 2006.

17. Yang SF, Wang PH, Lin LY, Ko JL, Chen GD, Yang JS, Lee HS and Hsieh YS: A significant elevation of plasma level of matrix metalloproteinase-9 in patients with high-grade intraepithelial neoplasia and early squamous cell carcinoma of the uterine cervix. Reprod Sci 14: 710-718, 2007.

18. Matheus ER, Zonta MA, Discacciati MG, Paruci P, Velame F, Cardeal LB, Barros SB, Pignatari AC and Maria-Engler SS: MMP-9 expression increases according to the grade of squamous intraepithelial lesion in cervical smears. Diagn Cytopathol 42: 827-833, 2014

19. Mathur SP, Mathur RS, Rust PF and Young RC: Human papilloma virus (HPV)-E6/E7 and epidermal growth factor receptor (EGF-R) protein levels in cervical cancer and cervical intraepithelial neoplasia (CIN). Am J Reprod Immunol 46: 280-287, 2001.
20. Hsieh CY, Tsai PC, Tseng CH, Chen YL, Chang LS and Lin SR: Inhibition of EGF/EGFR activation with naphtho[1,2-b] furan-4,5-dione blocks migration and invasion of MDA-MB-231 cells. Toxicol In Vitro 27: 1-10, 2013.

21. Seitz O, Schürmann C, Pfeilschifter J, Frank S and Sader R Identification of the Fra-1 transcription factor in healing skin flaps transplants: A potential role as a negative regulator of VEGF release from keratinocytes. J Craniomaxillofac Surg 40: 379-386, 2012

22. Belguise K, Kersual N, Galtier F and Chalbos D: FRA-1 expression level regulates proliferation and invasiveness of breast cancer cells. Oncogene 18: 1434-1444, 2005.

23. Adiseshaiah P, Vaz M, Machireddy N, Kalvakolanu DV and Reddy SP: A Fra-1-dependent, matrix metalloproteinase driven EGFR activation promotes human lung epithelial cell motility and invasion. J Cell Physiol 216: 405-412, 2008.

24. Das A, Li Q, Laws MJ, Kaya H, Bagchi MK and Bagchi IC: Estrogen-induced expression of Fos-related antigen 1 (FRA-1) regulates uterine stromal differentiation and remodeling. J Bio Chem 287: 19622-19630, 2012

25. Menges CW, Baglia LA, Lapoint R and McCance DJ: Human papillomavirus type 16 E7 up-regulates AKT activity through the retinoblastoma protein. Cancer Res 66: 5555-5559, 2006.

26. Spangle JM and Münger K: The human papillomavirus type 16 E6 oncoprotein activates mTORC1 signalling and increases protein synthesis. J Virol 84: 9398-9407, 2010.

27. Cardeal LB, Boccardo E, Termini L, Rabachini T, Andreoli MA di Loreto C, Longatto Filho A, Villa LL and Maria-Engler SS: HPV16 oncoproteins induce MMPs/RECK-TIMP-2 imbalance in primary keratinocytes: Possible implications in cervical carcinogenesis. PLoS One 7: e33585, 2012.

28. Shiau MY, Fan LC, Yang SC, Tsao CH, Lee H, Cheng YW, Lai LC and Chang YH: Human papillomavirus up-regulates MMP-2 and MMP-9 expression and activity by inducing interleukin-8 in lung adenocarcinomas. PLoS One 8: e54423, 2013.

29. Stanley MA, Browne HM, Appleby M and Minson AC: Properties of a non-tumorigenic cervical keratinocyte cell line. Int J Cancer 43: 672-676, 1989.

30. Pray TR and Laimins LA: Differentiation-dependent expression of E1-E4 proteins in cell lines maintaining episomes of human papillomavirus type 31b. Virology 206: 679-685, 1995.

31. Toschi E, Rota R, Antonini A, Melillo G and Capogrossi MC: Wild-type p53 gene transfer inhibits invasion and reduces matrix metalloproteinase-2 levels in p53-mutated human melanoma cells. J Invest Dermatol 114: 1188-1194, 2000

32. Livak KJ and Schmittgen TD: Analysis of relative gene expression data using real-time quantitative PCR and the 2(-Delta Delta C(T)) Method. Methods 25: 402-408, 2001

33. Barillari G, Iovane A, Bonuglia M, Albonici L, Garofano P, Di Campli E, Falchi M, Condò I, Manzari V and Ensoli B: Fibroblast growth factor- 2 transiently activates the $\mathrm{p} 53$ oncosuppressor protein in human primary vascular smooth muscle cells: Implications for atherogenesis. Atherosclerosis 210: 400-406, 2010.

34. Bertelsen BI, Steine SJ, Sandvei R, Molven A and Laerum OD: Molecular analysis of the PI3K-AKT pathway in uterine cervical neoplasia: Frequent PIK3CA amplification and AKT phosphorylation. Int J Cancer 118: 1877-1883, 2006.

35. Du CX and Wang Y: Expression of P-Akt, NFkappa B and their correlation with human papillomavirus infection in cervical carcinoma. Eur J Gynaecol Oncol 33: 274-277, 2012

36. Xu F, Cao M, Shi Q, Chen H, Wang Y and Li X: Integration of the full-length HPV16 genome in cervical cancer and Caski and Siha cell lines and the possible ways of HPV integration. Virus Genes 50: 210-220, 2015.

37. Rusan M, Li YY and Hammerman PS: Genomic landscape of human papillomavirus-associated cancers. Clin Cancer Res 21: 2009-2019, 2015 .

38. Adler DH: The impact of HAART on HPV-related cervical disease. Curr HIV Res 8: 493-497, 2010

39. Justesen US: Protease inhibitor plasma concentrations in HIV antiretroviral therapy. Dan Med Bull 55: 165-185, 2008. 